\title{
5-7 yaş grubu çocukların geometri becerilerinin incelenmesi*
}

\section{Investigation of geometry skills of 5-7 years old children}

\author{
Türker Sezer ${ }^{1}$, Yıldız Güven ${ }^{2}$
}

\begin{abstract}
Makale Geçmişi
Geliş : :14 Ağustos 2019

Düzeltme : 16 Eylül 2019

Kabul : 17 Eylül 2019

Çevrimiçi : 18 Eylül 2019
\end{abstract}

\section{Makale Türü}

Arasturma Makalesi

\section{Article History}

Received : 14 August 2019

Revised : 16 September 2019

Accepted : 17 September 2019

Online : 18 September 2019

\section{Article Type}

Research Article
Öz: Bu araştırmada, 5-7 yaş grubu çocukların geometri becerilerinin yaş ve cinsiyet değişkenleri açısından incelenmesi amaçlanmıştır. Nicel araştırma kapsamında ve tarama modeline uygun olarak tasarlanan araştırmanın evrenini, İstanbul ili Anadolu yakasında bulunan, okul öncesi eğitim kurumlarına ve ilkokulların 1.sınıfina devam eden 5-7 yaş grubu çocuklar (333'ü 5 yaş, 210'u 6 yaș ve 211'i 7 yaș) oluşturmaktadır. Araştırmanın verileri, "Kişisel Bilgi Formu" ve "Erken Geometri Beceri Testi" kullanılarak elde edilmiştir. Araştırma sonucunda, yaş değişkenin çocukların geometri becerileri üzerinde farklılık oluşturduğu, cinsiyet değişkeninin ise herhangi bir farklılık oluşturmadığı tespit edilmiştir. 5-7 yaş grubu çocukların, şekillerin tipik (prototip) örneklerini ayırt etmede sorun yaşamadıkları; ancak şekil seçiminde şekillerin atipik ve geçersiz örneklerinden etkilendikleri belirlenmiștir. Ayrıca șekil seçiminde çocukların daha çok görsel eşleştirme yapmalarının yanı sıra şekillerin basit özelliklerine yönelik eşleştirmeler yaptıkları da tespit edilmiştir. Araştırmada Clements ve diğgrlerinin (1999) ileri sürdüğ̈̈ tanıma öncesi dönemin (pre-recognitive) ve bütünleşik (syncretic) düzeyin varlığına yönelik kanıtlar elde edilmiştir.

Anahtar Kelimeler: Erken çocukluk matematik eğitimi; Geometri becerileri; Temel geometrik şekiller; Üç boyutlu şekiller

Abstract: In this study, it was aimed to examine geometric skill levels of children in the specified age group in terms of age and gender. The sample, which is designed in quantitative research scope and line with survey model, consists of 5-7 year-old children (333 five-year-old, 210 six-year-old and 211 sevenyear-old) attending pre-schools and first grades in Istanbul. Data were obtained by "Personal Information Form" and "Early Geometry Skills Test". As a result of the research, it was determined that age make a difference in geometry skills of the children while the gender variable makes no difference. It was identified that 5-7 year-old children do not have any difficulty in distinguishing typical samples of the shapes; but in the shape selection task, they are affected by atypical and non-valid examples. It was also determined that besides visual matching children make matches related to the simple properties of shapes, too. As a result of the findings, evidences for the existence of the pre-recognitive and syncretic level, which Clements et al (1999) put forward, was obtained.

Keywords: Mathematic education in early childhood; Geometry skills; Basic geometric shapes; 3D shapes 


\section{SUMMARY}

\section{Introduction}

Geometry needs to be addressed starting from early ages because it includes both concrete objects and shapes and contributes to learning mathematics. In order to do this, the development of geometric thinking in children should be understood (Olkun and Toluk Uçar, 2007). In recent years, the theory that is most widely utilized in the world for the development of geometric thinking skills in children is van Hiele's theory (Aslan and Aktaş-Arnas, 2007; Olkun and Toluk Uçar, 2007). According to van Hiele, there are five phases in the acquisition of geometric information (van Hiele, 1986, 1999). Although van Hiele's research is based on a educational basis, it seems to neglect young children. Both van Hiele's theory and the majority of their research focused on secondary school students and students in upper grades (van Hiele, 1986).

Over the last decade, research in the field of preschool mathematics in Turkey has focused on skills such as numbers, counting and arithmetic operations (Aktaş-Arnas, 2002; Akuysal-Aydoğan and Şen, 2011; Develi and Orbay, 2003; Erbay, 2009; Krrlar, 2006; Ömercikoğlu, 2006; Önkol, 2012; Poyraz and Turhan, 2006; Sezer and Güler-Öztürk, 2011; Taşkın, 2012; Turhan, 2004; Yiğit, 2008). In addition, studies investigating primary and secondary school students' geometry skills were densely concentrated on fourth graders and students in higher grades (Akbay Şener, 2012; Erdoğan, Akkaya and Akkaya Çelebi, 2009; Kilıç, Köse, Tanışlı and Özdaş, 2007; Terzi, 2010; Tutak, 2008; Ubuz, 1999; Yılmaz, 2011). These studies indicate that geometry skills of students are neglected in preschool and early school years (up to $4^{\text {th }}$ grade) and this finding is compatible with the literature.

Since there is a lack of information and data on the development of geometric thinking levels in young children, findings that will be obtained from new studies can provide some insight about children's recognition of basic shapes (Siew-Yin, 2003). For this reason, comparative studies are required in teaching geometry during early childhood years (Clements et al., 1999; Ness, 2001; Schrier, 1994; Siew-Yin, 2003). In this context, this study aimed to examine the geometry skills of 5-7 year old preschoolers and first graders based on age and gender variables.

\section{Method}

The quantitative study was designed by utilizing the survey model. The study group was composed of a total 754 5-7 year-old children (333 five-year-olds, 210 six-year-olds and 211 seven-year-olds) attending MoNE affiliated state and private preschools and primary schools in Anatolian part of Istanbul. Study data were obtained by "Personal Information Form" and "Early Geometry Skills Test (EGST)" developed by the researcher. Descriptive statistics (percentage, frequency, mean) and difference tests ( $t$ test, analysis of variance) were used during data analysis. 


\section{Results}

A significant difference was identified in mean EGST scores according to children's age $\left(\mathrm{F}_{(2,751)}=338,441\right.$, $\mathrm{p}<.05)$. The significant difference in the mean scores of EGST was found to be in favor of 6 year old children between 5 and 6 year old children; in favor of 7 year old children between 5 and 7 year old children and in favor of 7 year old children between 6 and 7 year old children. It was identified that the majority of children in the 5-7 age group named typical basic shapes and had problems distinguishing shapes among typical, atypical and invalid examples. It was determined that children's ability to draw shapes increased with age. It was also found that children knew characteristics of shapes such as edge and corner and exhibited the ability to mentally rotate shapes (although it was lower for 5 year olds).

In addition to these findings, children were found to be able to create new shapes by combining and dividing them. Furthermore, it was found that children in the 5-7 age group could name three-dimensional shapes. It was determined that the skill of repeating patterns developed with age, but the perspective-taking skills were found to be low in all age groups. It was also observed that the children predicted the two-dimensional trace of a three-dimensional object on paper. Based on these findings, it can be argued that gender is not a statistically significant factor which affects children's geometry skills $(\mathrm{t}=1,426, \mathrm{p}>.05)$.

\section{Conclusion and Discussion}

The results of the study present a significant difference in mean EGST scores of 5-7 year old children based on age. Relevant literature indicates similar results (Aktaş-Arnas and Aslan, 2010; Clements et al., 1999; Hannibal, 1999; Hung and Fang, 2010; Rosser, Campbell and Horan, 1986).

It was determined that children were able to distinguish typical (prototype) samples of triangles, squares, rectangles and circles. Research shows that the ability to match shapes is visual and prototype based (Clements et al., 1999; Hannibal, 1999; Siew-Yin, 2003). When non-typical examples of shapes were presented together with typical examples, shape characteristics such as ratio, rotation, openness and closeness affected the ability of children in this age group in distinguishing shapes. Similar results were obtained in various other studies (Aktaş-Arnas and Aslan, 2005, 2010; Aslan and Aktaş-Arnas, 2007; Clements et al., 1999; Fisher et al., 2013; Hannibal and Clements, 2000; Kesicioglu, 2011; Siew-Yin, 2003). It had already been concluded that children did not name shapes by looking at the whole, but also evaluated shape characteristics (edge-corner) (Clements et al., 1999; Hung and Fang, 2010; Siew-Yin, 2003). In addition, the result obtained in this study, which presented that children create new shapes by combining or dividing them, is a significant finding. This skill affects children's ability to define, use and visualize shapes (Clements, Wilson and Sarama, 2004).

It was found that children had a high level of success in shape-base relationships, but their ability to take perspective was generally low, although it increased with age. The findings of other studies also confirmed that children's perspective-taking skills were low in the early period (Aaten et al., 2011; Rigal, 1996). 
In conclusion, the study supports the thesis of Clements et al. (1999) stating that there is a pre-recognitive level before the visual level, and that the level that van Hiele has determined as visual level should be conceptualized as the syncretic level. It is suggested that information based on verbal explanation and imaginary information are sythesized and they interact with each other (Aslan and Aktaş-Arnas, 2007; Clements and Battista, 1992; Clements et al., 1999; Koleza and Giannisi, 2013; Siew-Yin, 2003). Children who participated in the research were able to visually distinguish shapes as well as presenting verbal information about the properties of shapes such as corners and edges. 


\section{GİRIŞ}

Matematiğin bir alanı olan geometri şekilleri, boyutu, pozisyonu, yönü ve hareketi içeren, içinde yaşadığımız fiziksel dünyayı tanımlayan ve sınıflandıran bir kavramdır (Copley, 2000). Bir başka tanımda, geometri uzayda nesnelerin mekânsal özellikleri, ilişkileri ve dönüşümleri çalışması olarak ifade edilmiştir (Clements ve Battista, 1992). Öğrencilerin içinde yaşadıkları dünyayı analiz etmelerine ve yorumlamalarına olanak sağlar (Özerem, 2012; Pesen, 2003). Diğer bir yandan eleştirel düşünme ve problem çözme becerilerinin gelişiminde önemli rol oynar (Hacısalihoğlu, Mirasyedioğlu ve Akpınar, 2003; Pesen, 2003).

Geometri öğretimi, gelişimsel olarak uygun ve çocukların dikkatini çeken programlarla bütünleştirilerek gerçekleştirilmelidir (Schrier, 1994). Geometrinin hem somut cisimler hem de şekilleri içermesi ve matematik öğrenimine olan katkısı nedeniyle daha erken yaşlardan itibaren ele alınması gerekir. Bunun yapılabilmesi için öncelikle çocukta geometrik düşüncenin nasıl geliştiği bilinmelidir (Olkun ve Toluk Uçar, 2007). Çocukların geometrik şekil kavramı üzerine odaklanan araştırmalar 1950'lerde başlamıştır. Piaget ve Inhelder "The Child's Conception of Space" başlıklı kitaplarında çocukların geometrik gelişiminde üç aşama olduğunu ileri sürmüşlerdir. Bu aşamalar; a) Topolojik (topological), b) İzdüşümsel/projektif (projective), c) Öklid (Euclidean) şeklinde sıralanmıştır (Piaget ve Inhelder, 1967). Son y1llarda çocuklarda geometrik düşünme becerisinin gelişimi adına dünyada yaygın bir şekilde kullanılan teori van Hiele’nin teorisidir (Aslan ve AktaşArnas, 2007; Olkun ve Toluk Uçar, 2007). van Hiele’ye göre geometrik bilgi kazanımı beş düzeye ayrılmaktadır (van Hiele, 1986, 1999). van Hiele’nin geometrik düşünme düzeylerinin ilki görsel düzeydir ve bu düzeyde şekiller görünüşlerine göre değerlendirilir. İkinci düzey olan analitik düzeyde bir şekil sahip olduğu özellikler ile değerlendirilir. Şekillerin özellikleri ve bileşenleri analiz edilir; özellikler ve kurallar deneysel olarak keşfedilir. İnformal çıkarım düzeyi üçüncü düzeydir ve şekillerin özellikleri mantıksal olarak düzenlenir. Dördüncü düzeydeki bir öğrenci aksiyom, teorem ve tanımlara dayalı olarak yapılan bir ispatın anlam ve önemini kavrayabilir ve buna yönelik bir anlayış geliştirir. Beşinci ve en ileri düşünme düzeyindeki bir kişi değişik aksiyomatik sistemler arasındaki farlılıkları anlayabilir (Altun, 1998; Crowley, 1987; Fuys, Geddes, Lovett ve Tischler, 1988; Hoffer, 1981; Olkun ve Toluk Uçar, 2007; Pesen, 2003; Szinger, 2008; Usiskin, 1982; van Hiele, 1986, 1999). Dördüncü ve beşinci düzeye orta ve yükseköğretim seviyesinde ulaşılmaktadır (Szinger, 2008).

van Hiele'nin araştırması eğitimsel bir temel üzerine yapılandırılmış olmasına rağmen küçük çocukların bu anlamda ihmal edildiği anlaşılmaktadır. Teorinin orijinalinde ve yaptıkları 
araştırmaların çoğunluğunda odak nokta olarak ortaokul ve daha ötesi incelenmiştir (van Hiele, 1986). Geometri ve mekânsal düşünme becerilerine erken çocukluk eğitiminde gereken önem verilmemektedir (Sarama ve Clements, 2003).

Türkiye'de son on yılda okul öncesi dönemde matematik alanında yapılan araştırmalar incelendiğinde bu araştırmalarda çoğunlukla sayı, sayma ve işlem gibi becerilerin araştırıldı̆̆ görülebilir (Aktaş-Arnas, 2002; Akuysal-Aydoğan ve Şen, 2011; Develi ve Orbay, 2003; Erbay, 2009; Kırlar, 2006; Ömercikoğlu, 2006; Önkol, 2012; Poyraz ve Turhan, 2006; Sezer, 2008; Sezer ve Güler-Öztürk, 2011; Sezer, Güral, Güven ve Efe-Azkeskin, 2013; Taşkın, 2012; Turhan, 2004; Yılmaz, 2006; Yiğit, 2008). Şekil ve sayı kavramlarının birlikte incelendiği (Sancak, 2003; Ölekli, 2009; Yalım, 2009), ayırıca çocukların matematik becerilerinin incelenmesi adı altında çeşitli beceriler araştırılmıştır (Dere, 2000; Ergün, 2003; İrkörücü, 2006; Köse, 2005; Polat-Unutkan, 2007; Sarıtaş, 2010). Çocukların geometri becerilerinin araştırıldığı çalısmalarda sadece şekil seçme becerisi ele alınmıştır (Çalıkoğlu Bali ve Boz, 2004; Sancak, 2003; Yalım, 2009). Ayrıca ilkokul ve ortaokullarda bulunan öğrencilerin geometri becerilerinin incelendiği araştırmalar çoğunlukla ilkokul 4. sınıf ve sonrasına yöneliktir (Akbay Şener, 2012; Çelebi Akkaya, 2006; Erdoğan, Akkaya ve Akkaya Çelebi, 2009; Kılıç, Köse, Tanışlı ve Özdaş, 2007; Terzi, 2010; Tutak, 2008; Ubuz, 1999; Yılmaz, 2011). Bütün bu araştırma sonuçları birlikte değerlendirildiğinde, okul öncesi dönem ve ilkokulun 4. sınıfına dek öğrencilerin geometri becerilerinin ihmal edildiği ve bu durumun alan yazınla uyumlu olduğu görülmektedir.

Bu yüzden öğretmenler ve programcılar sık sık erken çocukluk sınıflarındaki çocukların çok az ya da basit şekilleri tanımlama bilgilerinin hiç olmadığını zannetmektedirler (Thomas, 1982: akt. Clements, Swaminathan, Hannibal ve Sarama, 1999). Açık bir biçimde bu düşünce yanlıştır. Okul öncesi sınıflarındaki çocuklar, geometrik şekillerin temel formlarına yönelik bilgilerini kâğıt-kalem çalışmalarında bile sergileyebilirler. Öğretim, bu bilgileri inşa ederek çocukların daha öteye geçmelerini sağlamalıdır. Öğrencilerin görsel düzeyden öteye geçememelerinin sebebi, erken yaşlarda geometriye yönelik problem durumlarının sunulmamasından kaynaklanmaktadır (van Hiele, 1987: akt. Clements vd., 1999).

Öğretmenlerin çok azı şekillerin isimlendirilmesi, fark edilmesi, materyaller kullanılarak geometrik inşa çalışmaları içerisinde, çocukların becerilerinin geliştirilmesine yönelik çalışmalar yapmaktadır (Aydın, 2009). Clements (1999a), çocukların okula temel geometrik bilgiyle geldiklerini ama uygulamaların çocuklarda hali hazırda var olan kavramların kavramsal değişimlerini sağlayamadığını belirtmiştir. Çocukların geometri ile ilgili bilgilerini geliştirmek için erken çocukluk sınıflarında çok 
az firsat olmasından dolayı, okulda çocukların çoğuna geometrik ve mekansal düşünmelerini desteklemek için kapasitelerini geliştirecek geometri etkinlikleri sunulmamaktadır. Çünkü öğretmenler genellikle geometri öğretiminde şekillerin görsel tipik (prototip) örneklerini kullanmakta ve şekillerin atipik örneklerine yer vermemektedir (Siew-Yin, 2003). Çarpıcı bir örnek olarak geometrik şekillerin öğretimini temel alan dergi, kitap ve CD’lerde çoğunlukla geometrik şekillerin tipik örneklerinin sunulduğu saptanmıştır. Şekillerin öğretiminde, basılık, çarpıklık, konum ve boyut gibi özellikleri içeren atipik örneklere ise çok az yer verildiği belirlenmiştir (Aslan ve Aktaş-Arnas, 2007). Oysaki öğrencilerin kavram kazanımında atipik örneklerin kullanılması onların kavram düzeylerinin belirlenmesi ve öğretmenin öğrencisinin geometrik düşünme düzeyi hakkında bilgi edinmesine önemli katkılar sağlamaktadır (Tsamir, Tirosh, ve Levenson, 2008). Şekillere yönelik sunulan sınırlı örneklerin çocukların geometrik şekiller ile ilgili oluşturdukları şemalar1 engellediği ifade edilmiştir (Clements vd., 1999). Öğretmenlerin geometri öğretiminde şekillerin tipik, atipik ve geçersiz örneklerini birlikte kullanmaları gerekmektedir.

Geometrik düşünme düzeyleri bakımından çocukların gelişimine yönelik bilgi ve verinin yetersiz olmasından dolayı, yapılacak araştırmalardan elde edilen bulgular sşığında, çocukların temel şekilleri fark etmelerindeki anlayışları konusunda bazı öngörüler elde edilebilir (Siew-Yin, 2003). Bu sebeple erken çocukluk yıllarında geometri öğretimine yönelik karşılaştırmalı araştırmaların yapılmasına ihtiyaç duyulmaktadır (Clements vd., 1999; Ness, 2001; Schrier, 1994; Siew-Yin, 2003). Bu bağlamda araştırmanın amacı, 5-7 yaş grubunda olan, okul öncesi eğitim ve ilkokul 1.sınıfa devam eden çocukların geometri becerilerinin yaş ve cinsiyet değişkenleri açısından incelenmesidir.

\section{YÖNTEM}

\section{Araştırmanın Modeli}

Araştırma, nicel araştırma kapsamındadır ve tarama modeline uygun olarak tasarlanmıştır. Özel olaylar ve olgular arasında var olan ilişkileri belirleme, bir durumun karşılaştırılması sonucunda ortaya çıkan standartları tanımlama, bu durumun doğasının anlaşılması için zaman içerisinde belirli bir noktada veri elde edilmesi amaçlandığ için tarama modeli bu araştırmaya uyundur (Cohen, Manion ve Morrison, 2005; Karasar, 2013).

\section{Çalışma Grubu}

İstanbul ili Anadolu yakasındaki 14 ilçe arasından kolay ulaşılabilirlik ilkesi göz önüne alınarak Ataşehir, Kadıköy ve Maltepe ilçeleri seçilmiştir. Daha sonra araştırmanın çalışma grubu İstanbul 
ili Anadolu yakasında yer alan ve Milli Eğitim Bakanlığı'na bağlı devlet ve özel okul öncesi eğitim kurumlarına ve ilkokulların 1.sınıflarına devam eden, normal gelişim gösteren 5, 6 ve 7 yaş grubunda bulunan toplam 754 çocuktan oluşturulmuştur. Araştırmaya 5 yaş grubundan 333 (\% 44,2), 6 yaş grubundan $210(\%$ 27,9) ve 7 yaş grubundan 211 (\% 28) çocuk katılmıştır. Ayrıca 5 yaş grubunun ay ortalaması 64,11, 6 yaş grubunun ay ortalaması 73,52 ve 7 yaş grubunun ay ortalaması 85,47'dir. Çocukların 351' kız $(\% 46,6)$ ve 403’ü $(\% 53,4)$ erkektir. 157’si $(\% 20,8)$ anasınıfina, 248’i $(\% 32,9)$ anaokuluna ve 349'u $(\% 46,3)$ ilkokul 1 . sinıfa devam etmektedir.

\section{Veri Toplama Araçları}

Araştırmanın verileri "Kişisel Bilgi Formu" ve "Erken Geometri Beceri Testi (EGBT)" kullanılarak elde edilmiştir.

\section{Kişisel bilgi formu}

Araştırmacı tarafından, 5-7 yaş grubundaki çocukların ve ailelerinin demografik özelliklerini belirlemek amacıyla "Kişisel Bilgi Formu” hazırlanmıştır. Bu form ile çocuk ve ailesi hakkında bilgi toplanması amaçlanmıştır. Formda çocuğun yaşı, cinsiyeti, devam ettiği okul türünü öğrenmeye yönelik sorulara yer verilmiştir.

\section{Erken geometri beceri testi}

Araştırmacı tarafından, 5-7 yaş grubundaki çocukların geometrik düşünme becerilerinin belirlenmesinde kullanılmak üzere geliştirilen EGBT'de yer alan her bir madde için Kapsam Geçerlik İndeksi, .65’tir. Erken Sayı Testi ve Frostig Görsel Algılama Testi, 5-7 Yaş Grubu Çocuklar için EGBT'nin kriter geçerliği için kullanılmıştır. Testin toplam güvenirlik katsayısı için KR20 katsayıs1 .853'tür. Testinin iki yarısı arasında Pearson Korelasyon katsayıs1 .697'dir. Ayrıca testin ilk yarısı için Cronbach's Alpha değeri: .764 ve ikinci yarısı için: .856'dır. Bunların yanında testin testtekrar test sonuçları Pearson Korelasyon katsayısı için: .898'dir. Test, 42 maddeden oluşmaktadır ve maddelerin puanlanması doğru-yanlış üzerine yapılandırılmıştır. Puanlama yapılırken; M1, M2, M3, M8, M9, M10, M11, M12, M13, M14, M15, M16, M17, M18, M19, M20, M21, M22, M23, M24, M25, M26, M27, M28, M29, M30, M31, M32, M33, M34, M35, M36, M37, M38, M40, M41 ve M42 için doğru cevap “1”, yanlış cevap “ 0 ” olarak puanlanmaktadır. M4 (toplam sekiz puan), M5 (toplam sekiz puan), M6 (toplam sekiz puan), M7 (toplam altı puan), M39 (toplam dört puan) için değerlendirme puan anahtarına göre yapılarak toplam puanlar ile değerlendirilmektedir. Çocuklar ile bire bir uygulanan EGBT'nin uygulama süresi yaklaşık olarak 30-45 dakika arasında 
değişim göstermiştir. Aşağı̆da testte yer alan maddelerin beceri grupları sunulmuştur (Sezer, 2015; Sezer ve Güven, 2016).

Tablo 1. EBGT'de yer alan beceriler, becerileri barındıran maddeler

\begin{tabular}{|c|c|c|c|}
\hline Beceriler & Madde No & Beceriler & Madde No \\
\hline $\begin{array}{l}2 \text { Boyutlu şekillerin tipik örneklerini } \\
\text { tanıma }\end{array}$ & $\begin{array}{l}\text { (M1) } \\
\text { (M2) } \\
\text { (M3) } \\
\text { (M4) }\end{array}$ & Şekil oluşturma 3 (çubuklar ile) & $\begin{array}{l}\text { (M22) } \\
\text { (M23) } \\
\text { (M24) } \\
\text { (M25) }\end{array}$ \\
\hline $\begin{array}{l}2 \text { Boyutlu Şekil seçme (tipik, atipik, } \\
\text { geçersiz örnekler) }\end{array}$ & $\begin{array}{l}\text { (M5) } \\
\text { (M6) } \\
\text { (M7) } \\
\text { (M8) }\end{array}$ & Şekil-Zemin ilişkisi & $\begin{array}{l}\text { (M26) } \\
\text { (M27) }\end{array}$ \\
\hline 2 Boyutlu Şekil çizime & (M9) & & $(\mathrm{M} 29)$ \\
\hline $\begin{array}{l}2 \text { Boyutlu şekillerin özelliğini bilme } \\
\text { (kenar-köşe) }\end{array}$ & $\begin{array}{l}\text { (M11) } \\
\text { (M12) } \\
\text { (M13) }\end{array}$ & 3 Boyutlu şekilleri tanıma & $\begin{array}{l}\text { (M30) } \\
\text { (M31) } \\
\text { (M33) }\end{array}$ \\
\hline Şekil oluşturma 1 (zihinden) & $\begin{array}{l}\text { (M14) } \\
\text { (M15) } \\
\text { (M16) } \\
\text { (M17) }\end{array}$ & Örüntü & $\begin{array}{l}\text { (M34) } \\
\text { (M35) } \\
\text { (M36) } \\
\text { (M37) }\end{array}$ \\
\hline Şekil ayırma & $\begin{array}{l}\text { (M18) } \\
\text { (M19) }\end{array}$ & $\begin{array}{l}\text { Perspektif alma } \\
\text { Bloklarla inşa }\end{array}$ & $\begin{array}{l}\text { (M38) } \\
\text { (M39) }\end{array}$ \\
\hline Şekil oluşturma 2 (materyal ile) & $\begin{array}{l}\text { (M20) } \\
(\mathrm{M} 21)\end{array}$ & $\begin{array}{l}3 \text { Boyutlu şekillerin yüzeyini tahmin } \\
\text { etme }\end{array}$ & $\begin{array}{l}\text { (M40) } \\
\text { (M41) } \\
\text { (M42) }\end{array}$ \\
\hline
\end{tabular}

\section{Verilerin toplanması ve analizi}

EGBT 2013-2014 eğitim-öğretim yllında çalışma grubuna dahil edilen okullarda uygulanmıştır. Ayrıca Kişisel Bilgi Formunda yer alan bilgilerin elde edilmesinde çocukların okul kayıtları yapılırken ailelerinden alınan bilgilere ulaşılmış ve demografik değişkenler bu uygulama ile oluşturulmuştur. Test uygulanırken okullarda uygun bir oda ya da uygun bir alana bir masa ve yan yana iki sandalye yerleştirilmiş ve testin uygulaması çocuklar ile bire bir gerçekleştirilmiştir. Uygulama toplam 754 çocukla yürütülmüştür. Testin uygulama süresi ortalama 30-40 dakika sürmektedir. Çocukların geometri becerileri yaş ve cinsiyet değisskenlerine göre incelenirken tanımlayıcı istatistikler (yüzde, frekans, ortalama) ve fark testleri ( $\mathrm{t}$ testi, Varyans analizi) kullanılmıştır. Bunlara ek olarak istatistiksel önemlilik düzeyi 0,05 olarak kabul edilmiştir.

\section{BULGULAR}

Bu bölümde 5-7 yaş grubundaki çocukların geometri becerileri yaş ve cinsiyet değişkenine göre incelenmiş ve bulgular sunulmuştur. 
Tablo 2. Çocukların erken geometri beceri testi puan ortalamalarının yaş değişkenine göre ANOVA sonuçları

\begin{tabular}{llllll}
\hline & KT & sd & KO & F & p \\
\hline Gruplararas1 & 65159,257 & 2 & 32579,629 & 338,441 &, $000^{*}$ \\
Gruplariçi & 72294,049 & 751 & 96,264 & & \\
Toplam & 137453,306 & 753 & & & \\
$* \not$ * $<.001$ & & & & &
\end{tabular}

Tablo 2'ye göre EGBT'den alınan puan ortalamaları arasında çocukların yaşlarına göre anlamlı farkl1lık olduğu bulunmuştur $\left(\mathrm{F}_{(2,751)}=338,441, \mathrm{p}<.05\right)$. Belirlenen bu farklıllı̆ın hangi gruplar arasında olduğunu bulmak için Post Hoc çoklu karşılaştırma analizi yapılmış, Levene istatistiği ile verilerin dağılımına bakılmış ve verilerin homojen dağılmadığı $(\mathrm{p}<.05)$ belirlenerek Tamhane’s 2 Testi yapılmıştır. Ortaya çıan sonuç Tablo 2'de sunulmuştur.

Tablo 3. Çocuklanın erken geometri beceri testi puan ortalamalarının yaş değişkenine göre Tamhane’s 2 testi sonuçları

\begin{tabular}{|c|c|c|c|}
\hline (I) Yaş & (J) Yaş & Ortalama Farkı (I-J) & $\mathrm{p}$ \\
\hline \multirow{2}{*}{5 yaş } & 6 yaș & $-16,76971$ &, $000^{*}$ \\
\hline & 7 yaş & $-20,28648$ &, $000^{*}$ \\
\hline \multirow{2}{*}{6 yaş } & 5 yaş & 16,76971 &, $000^{*}$ \\
\hline & 7 yaş & $-3,51677$ &, $000^{*}$ \\
\hline \multirow{2}{*}{7 yaş } & 5 yaş & 20,28648 & ,000* \\
\hline & 6 yaș & 3,51677 &, $000^{*}$ \\
\hline
\end{tabular}

Tablo 3 incelendiğinde, EGBT ortalama puanlarında ortaya çıkan anlamlı farklılı̆̆ın; 5 yaş grubu çocuklar ile 6 yaş grubu çocuklar arasında 6 yaş grubu lehine, 5 yaş grubu çocuklar ile 7 yaş grubu çocuklar arasında 7 yaş grubu lehine ve 6 yaş grubu çocuklar ile 7 yaş grubun çocuklar arasında 7 yaş grubu lehine olduğu bulunmuştur. Aşağıda EGBT’de yer alan sorulara çocukların verdikleri cevapların yüzdeleri ayrıntılı olarak sunulmuştur.

Şeklin tipik örneğini isimlendirme sorularının (M1, M2, M3) yaş değişkenine göre yüzde değerlerine bakılmış; 5 yaş grubunun \% 97,9’unun, 6 yaş grubunun \% 100’ünün ve 7 yaş grubunun \% 100'ünün karenin tipik örneğini, 5 yaş grubunun \% 90,7'sinin, 6 yaş grubunun \% 99,5'inin ve 7 yaş grubunun \% 99,1'inin dikdörtgenin tipik örneğini, 5 yaş grubunun \% 96,1'inin, 6 yaş grubunun \% 099,5 'inin ve 7 yaş grubunun \% 99,5’inin dairenin tipik örneğini doğru isimlendirdikleri bulunmuştur.

Şeklin tipik, atipik ve geçersiz örneklerini ayırt etme sorularının (M4, M5, M6, M7) yaş değisskenine göre ortalamaları incelenmiştir. Üçgen için 5 yaş grubunun ortalama puanı: 1,73, 6 yaş grubunun: 4,07 ve 7 yaş grubunun: 3,82'dir. Kare için 5 yaş grubunun ortalama puanı: 3,71, 6 yaş grubunun: 4,46 ve 7 yaş grubunun: 4,67'dir. Dikdörtgen için 5 yaş grubunun ortalama puanı: 3,70, 6 yaş 
grubunun: 5,01 ve 7 yaş grubunun: 4,81'dir. Ayrıca çember için 5 yaş grubunun ortalama puanı: 3,72, 6 yaş grubunun: 4,87 ve 7 yaş grubunun: 5,08'dir.

Şekil çizme sorularının (M8, M9, M10) yaş değişkenine göre yüzde değerleri incelenmiş, 5 yaş grubunun \% 36,3'ünün, 6 yaş grubunun $\% 81$ 'inin ve 7 yaş grubunun $\% 82,5$ 'inin örnekte verilen kare şeklini, 5 yaş grubunun \% 45,3'ünün, 6 yaş grubunun \%77,6'sının ve 7 yaş grubunun \% 86,3'ünün örnekte verilen dikdörtgen şeklini, 5 yaş grubunun \% 36,6’sının, 6 yaş grubunun \% 66,2'sinin ve 7 yaş grubunun \% 64'ünün örnekte verilen üçgen şeklini çizebildikleri bulunmuştur.

Şeklin kenar ve köşe özelliklerine (M11, M12) verilen cevaplara göre 5 yaş grubunun \% 62,2'sinin, 6 yaş grubunun \% 86,2'sinin ve 7 yaş grubunun \% 86,3’ünün şeklin kenar özelliğini, 5 yaş grubunun \% 40,5'inin, 6 yaş grubunun \% 61'inin ve 7 yaş grubunun \%81'inin şeklin köşe özelliğini fark ettikleri bulunmuştur.

Döndürme sorularının (M13, M14, M15) yaş değişkenine göre yüzde değerleri incelenmiş, 5 yaş grubunun \% 82'sinin, 6 yaş grubunun \% 91,9'unun ve 7 yaş grubunun \% 99,5'inin kare şeklini uygun boşluğa doğru yerleştirdikleri bulunmuştur. Ayrıca 5 yaş grubunun \% 55’inin, 6 yaş grubunun \% 71'inin ve 7 yaş grubunun \% 87,2'sinin $90^{\circ}$ döndürülmüş üçgen şeklini ve 5 yaş grubunun \% 63,4’ünün, 6 yaş grubunun \% 59,5’inin ve 7 yaş grubunun $\%$ 88,2'sinin $180^{\circ}$ döndürülmüş üçgen şeklini zihinden döndürüp uygun boşluklara yerleştirebildikleri tespit edilmiştir.

Şekil birleştirme (zihinden) sorularının (M16, M17) yaş değisskenine göre yüzde değerleri incelenmiş, 5 yaş grubunun $\%$ 46,2'sinin, 6 yaş grubunun \% 86,7'sinin ve 7 yaş grubunun \% 88,2'sinin en az iki parçayı birleştirerek beşgen şeklini oluşturdukları bulunmuştur. Bu bulgunun yanı sıra 5 yaş grubunun \% 53,2'sinin, 6 yaş grubunun \% 85,2'sinin ve 7 yaş grubunun \% 94,3’ünün bir tangram oluştururken kullanılması uygun olmayan şekilleri ayırt edebildikleri bulunmuştur.

Şekil ayırma (tahmin) sorularının (M18, M19) yaş değişkenine göre yüzde değerleri incelenmiş, 5 yaş grubunun \% 73,3'ünün, 6 yaş grubunun \% 90’ının ve 7 yaş grubunun \% 98,6'sının bir kareyi köşelerinden ayırarak iki üçgenin oluşabileceğini, 5 yaş grubunun \% 74,8’inin, 6 yaş grubunun \% 92,4'ünün ve 7 yaş grubunun \% 95,3'ünün bir kareden iki dikdörtgenin oluşabileceğini tahmin ettikleri bulunmuştur.

Şekil üretme (materyal ile) sorularının (M20, M21) yaş değişkenine göre yüzde değerleri incelendiğinde, 5 yaş grubunun \%17,1'inin, 6 yaş grubunun \%30'unun ve 7 yaş grubunun \% 22,3’ünün bir düzgün yamuk ve dik üçgeni birleştirerek dikdörtgen oluşturabildikleri, 5 yaş 
grubunun \% 43,5’inin, 6 yaş grubunun \% 61,9'unun ve 7 yaş grubunun $\%$ 47,9’unun iki dik üçgeni birleştirerek bir dikdörtgen ya da bir üçgen oluşturabildikleri bulunmuştur. Bu bulgunun yanında (M22, M23, M24) 5 yaş grubunun \% 61,6'sının, 6 yaş grubunun \% 85,7'sinin ve 7 yaş grubunun \% 86,7'sinin çubukları kullanarak kareyi, 5 yaş grubunun \% 29,4'ünün, 6 yaş grubunun \% 67,6’sının ve 7 yaş grubunun \% 69,2'sinin çubukları kullanarak dikdörtgeni oluşturabildikleri bulunmuştur. Ayrıca 5 yaş grubunun \% 50,5’inin, 6 yaş grubunun \% 80,5'inin ve 7 yaş grubunun \% 72,5’inin üç çubuğun kullanılması ile hangi şeklin oluşabileceğini (üçgen) doğru tahmin ettikleri bulunmuştur.

Mekân becerilerine yönelik soruların (M25, M26, M27) yaş değişkenine göre yüzde değerleri incelendiğinde, 5 yaş grubunun \% 83,2'sinin, 6 yaş grubunun \% 92,9’unun ve 7 yaş grubunun $\% 96,7$ 'sinin dörtte biri renklendirilmiş kare şeklinin aynısını bulduğu, 5 yaş grubunun \% 75,1'inin, 6 yaş grubunun \% 82,4’ünün ve 7 yaş grubunun \% 91'inin sekizde üçü renklendirilmiş kare şeklinin aynısını bulduğu belirlenmiştir. Ayrıca yine 5 yaş grubunun \% 75,7'sinin, 6 yaş grubunun \% 92,9’unun ve 7 yaş grubunun \% 99,1'inin sekizde dördü renklendirilmiş beşgen şeklinin aynısını bulduğu tespit edilmiştir.

Cisim sorularının (M28, M29, M30, M31, M32, M33) yaş değişkenine göre yüzde değerleri incelendiğinde, 5 yaş grubunun \% 18,6'sının, 6 yaş grubunun \% 70'inin ve 7 yaş grubunun \% 85,3'ünün silindiri, 5 yaş grubunun \% 25,2'sinin, 6 yaş grubunun \% 66,7'sinin ve 7 yaş grubunun \% 60,2'sinin dikdörtgenler prizmasını, 5 yaş grubunun \% 15,9'unun, 6 yaş grubunun \% 70'inin ve 7 yaş grubunun \% 78,2'sinin küpü, 5 yaş grubunun \% 6,9’unun, 6 yaş grubunun \% 46,7'sinin ve 7 yaş grubunun \% 58,3'ünün koniyi, 5 yaş grubu çocukların \% 22,8’inin, 6 yaş grubunun \% 56,2'sinin ve 7 yaş grubunun \% 79,6'sinin küreyi ayırt edebildikleri belirlenmiştir. Bu bulgulara ek olarak 5 yaş grubunun \% 11,1'inin, 6 yaş grubunun \% 54,3'ünün ve 7 yaş grubunun \% 55,5'inin küpün bir yüzeyinin şeklini tahmin edebildikleri bulunmuştur.

Örüntü sorularının (M34, M35, M36, M37) yaş değişkenine göre yüzde değerleri incelenmiş, 5 yaş grubunun \% 39'unun, 6 yaş grubunun \% 58,6'sının ve 7 yaş grubunun \% 70,1'inin iki birimli örüntüyü, 5 yaş grubunun \% 30,6'sının, 6 yaş grubunun \% 50,5’inin ve 7 yaş grubunun $\%$ 90,5'inin üç birimli örüntüyü, 5 yaş grubunun \% 20,1'inin, 6 yaş grubunun $\%$ 52,4’ünün ve 7 yaş grubunun \% 66,4'ünün dört birimli örüntüyü sürdürdükleri bulunmuştur. Bu bulguların yanı sıra 5 yaş grubunun \% 67'sinin, 6 yaş grubunun \% 60,5’inin ve 7 yaş grubunun \% 77,3’ünün dört birimli bir şekil grubunu 5 saniye baktıktan sonra hatırlayabildikleri belirlenmiştir. 
Perspektif sorusunun (M38) yaş değişkenine göre yüzde değerleri incelenmiş, 5 yaş grubunun \% 4,8’inin, 6 yaş grubunun \% 12,9’unun ve 7 yaş grubunun \% 20,9’unun perspektif sorusunu doğru cevapladığı bulunmuştur.

Bloklarla inşa sorusunun (M39) yaş değişkenine göre ortalama değerleri incelenmiş, 5 yaş grubunun bloklarla inşa sorusu ortalama puanı: 1,38, 6 yaş grubunun: 2,25 ve 7 yaş grubunun puanı: 2,51 olarak bulunmuştur.

Cisimlerin yüzlerini tahmin etme sorularının (M40, M41, M42) yaş değişkenine göre yüzde değerleri incelenmiş, 5 yaş grubunun \% 57,7'sinin, 6 yaş grubunun \% 84,3'ünün ve 7 yaş grubunun \% 74,9'unun dikdörtgenler prizmasının, 5 yaş grubunun \% 72,7’sinin, 6 yaş grubunun \% 77,1'inin ve 7 yaş grubunun \% 96,7’sinin küpün, 5 yaş grubunun \% 3'ünün, 6 yaş grubunun \% 19’unun ve 7 yaş grubunun \% 23,7’sinin üçgen prizmanın bir yüzeyinin kağıt üzerinde bıraktığı izi doğru tahmin edebildikleri bulunmuştur.

Tablo 4. Çocukların erken geometri beceri testi puan ortalamalarının cinsiyet değişkenine göre t testi sonuçları

\begin{tabular}{ccccccc}
\hline Cinsiyet & $\mathbf{N}$ & $\overline{\mathbf{X}}$ & Ss & Sd & $\mathbf{t}$ & $\mathbf{p}$ \\
\hline Krz & 351 & 42,11 & 12,51 & 752 & 1,426 &, 154 \\
Erkek & 403 & 40,79 & 12,82 & & & \\
\hline
\end{tabular}

Tablo 4'e göre EGBT ortalama puanlarında cinsiyet değişkeninin anlamlı bir farklılık oluşturmadığ1 bulunmuştur ( $\mathrm{t}=1,426, \mathrm{p}>.05)$.

\section{SONUÇ ve TARTIŞMA}

Araştırmada elde edilen bulgular sonucunda, 5-7 yaş grubu çocukların EGBT puan ortalamalarında yaşlarına göre anlamlı bir farklılık olduğu görülmüştür. Ortaya çıkan anlamlı farklılığın; 5 yaş grubu çocuklar ile 6 yaş grubu çocuklar arasında 6 yaş grubu lehine, 5 yaş grubu çocuklar ile 7 yaş grubu çocuklar arasında 7 yaş grubu lehine ve 6 yaş grubu çocuklar ile 7 yaş grubun çocuklar arasında 7 yaş grubu lehine olduğu tespit edilmiştir. İlgili alan yazın incelendiğinde bir çok araştırmada benzer sonuçlara ulaşıldığ1 görülmektedir (Aktaş-Arnas ve Aslan, 2010; Clements vd., 1999; Hannibal, 1999; Hung ve Fang, 2010; Rosser, Campbell ve Horan, 1986). Bir başka ifade ile çocukların yaşları arttıkça geometri becerilerinde de artış olduğu söylenebilir.

Çocukların testte yer alan sorulara verdikleri cevapların doğru-yanlış olarak incelenmesi sonucunda, üçgenin, karenin, dikdörtgenin ve çemberin tipik (prototip) örneklerini ayırt edebildikleri belirlenmiştir. Yapılan araştırmalar, çocukların şekil eşleştirmelerinin görsel ve tipik örnek (prototip) 
temelli olduğunu göstermektedir (Clements vd., 1999; Hannibal, 1999; Siew-Yin, 2003). Çocuklar bir şekil sınıfının öğelerini belirlerken sözel tanımlamadan öte, şeklin tipik örneğini tercih etmektedirler (Hung ve Fang, 2010; Özerem, 2012).

Şekillerle ilgili tipik olmayan örnekler ile tipik örnekler birlikte sunulduğunda, çocukların tüm yaş gruplarında şekil seçiminde hata oranlarının arttığı sonucuna ulaşılmıştır. Sunulan şekillerin oran, döndürme, açılık, kapalılık gibi özelliklerinin bu yaş grubundaki çocukların şekilleri ayırt etme becerilerini etkilediği görülmüştür. Yapılan birçok araştırmada da benzer sonuçlara ulaşılmıştır (Aktaş-Arnas ve Aslan, 2005, 2010; Aslan ve Aktaş-Arnas, 2007; Clements vd., 1999; Fisher vd., 2013; Hannibal ve Clements, 2000; Kesicioğlu, Alisinanoğlu ve Tuncer, 2011; Kesicioğlu, 2011). İlkokula ve ortaokula devam eden öğrencilerin de şekil seçimlerinde tipik örnek etkisi bulunmuştur (Rønning, 2004; Siew-Yin, 2003; Tsamir, Tirosh ve Levenson, 2008; Vighi, 2003). Kao (2002), bir şeklin kapalılık, pozisyon ve boyut özelliklerinden kaynaklanan mekânsal kavramlarda, çocukların kavram yanlışları yaptıklarını bulmuştur (Akt., Hung ve Fang, 2010).

Çocukların şekil çizme becerilerinin yaşa bağlı olarak farklılaştığı görülmüştür. İlgili alan yazın incelendiğinde benzer sonuçlara ulaşılan araştırmalar bulunmaktadır (Çalıkoğlu-Bali ve Boz, 2004). Clements ve diğerleri (2011) tarafindan okul öncesi dönemde bulunan 1375 çocuk ile yapilan araştırma sonucunda, şekiller ile ilgili becerilerin desteklenmesinde şekil çizimi, inşası, analizi ve şekillerin özelliklerine ilişkin tartışma etkinliklerinin önemli bir etkiye sahip olduğu görülmüştür. Hung ve Fang (2010) tarafindan yapılan araştırmada da çocukların geometrik şekil çizimlerinin sınıf düzeylerine göre farklılık gösterdiği ve sınıf düzeyi arttıkça geometrik şekil çizimindeki başarının arttı̆̆1 görülmüştür.

Araştırmada ortaya çıkan bir başka sonuç, şeklin kenar özelliğinin, köşe özelliğinden daha fazla doğru cevaplanmış olmasıdır. Buradan yola çıkarak bu yaş grubundaki çocukların şekilleri sadece bütüne bakarak isimlendirmedikleri, şekillerin özelliklerine ilişkin de değerlendirmeler yaptıkları ifade edilebilir. Clements ve diğerleri (1999) ile Hung ve Fang (2010) yaptıkları çalışmada, araştırmaya katılan çocukların bazılarının şekilleri seçerken, şeklin özelliğine yönelik açılamalar yaptığını tespit etmişlerdir. Şeklin özelliğine yönelik açılamalar yapan çocukların şekil seçimleri, açıklama yapmayan çocuklara göre anlamlı derecede farklılık göstermiştir. Clements ve diğerleri (2011) tarafindan yapılan bir başka araştırmada da geometrik becerilere yönelik program uygulanan deney grubundaki çocukların, şekilleri ve şeklin öğelerini tanıma becerilerinin diğer beceriler ile ilişkili olduğu ve bu beceri ediniminin en önemli kazanım olduğu sonucuna varılmıştır. Buna ek olarak çokgenlerin köşe ve kenar sayılarının belirlenmesi ve tanınmasının da araştırmanın en geniş 
kapsamlı kazanımı olduğu görülmüştür. Bu sonuçları destekleyen bir diğer araştırmada ise kare ve çember şekilleri için en baskın cevabın, şeklin özelliğine ilişkin cevap olarak kabul edilen kenar sayısı olduğu görülmüştür (Siew-Yin, 2003). Bu araştırmaların aksine Kaur (2012), tarafından yapılan araştırmada, öğrencilerin çoğunun kenar kavramına sahip olmadıklarını belirlemiştir. Araştırmaların sonuçlarının farklılık göstermesinin nedenleri arasında örneklem farklılıkları, program farklılıkları, ölçüm farklılıkları ve öğretmen farklılıkları gösterilebilir.

Şekillerin döndürülmesine ilişkin sorulara verilen cevaplarda da yaş arttıkça doğru cevap yüzdesinin arttığ1 tespit edilmiştir. Çocukların niteliksel akıl yürütme becerilerindeki gelişimin desteklenmesinde, şekillerin döndürülmesi kritik bir öneme sahiptir (Greenstein, 2011). Clements (1999a), şekillerin zihinsel olarak döndürülmesini, mekânsal akıl yürütme olarak ifade etmektedir. Zihinsel imgeleri döndürme ve kaydırma becerisi, günlük yaşantımızda gerekli bir beceridir. Çünkü geometri eğitiminin bir amacı da bireylere, problemleri farklı bakış açılarıyla görebilme becerisi kazandırmak olarak açıklanmıştır (Thirumurthy, 2003). Küçük çocuklar çoğu zaman bir şeklin döndürüldüğü, kaydırıldığı, çevrildiği zaman neye benzediğini görselleştirmede başarısız olurlar. Copley (2000) tarafindan 4 yaş grubu çocuklar ile yapılan bir araştırmada, karenin çapraz döndürülerek kesildiğinde iki üçgen elde edilip ve bu üçgenler tekrar bir araya getirildiğinde kare oluşmasını gözlemlediklerinde şaşırdıkları görülmüştür. Çocukların bu tür çalışmaları sıkça yapmaları ve değişiklikleri gözlemlemeleri gerekmektedir (Szinger, 2008).

Çocukların, şekilleri zihinlerinde döndürerek birleştirebildikleri ve yeni şekli oluşturabildikleri görülmüştür. Şekillerin birleştirilerek ya da bir şeklin uygun biçimde ayrllarak yeni şekiller elde edilmesine ilişkin ortaya çıkan sonuçlar, bu araştırmada elde edilen önemli sonuçlarındandır. Aynı şekilde bu becerilerin de yaşa bağlı olarak gelişim gösterdiği görülmüştür. Geometrik şekillerin farklı şekillerden oluşturulması ve bir şekilden başka şekiller elde edilmesinin çocukların şekilleri tanımlama, kullanma ve görselleştirme becerisine etkisi, geometri alanı içerisinde bir beceri grubu ve önemli bir kavramsal alan olarak belirtilmiştir (Clements, Wilson ve Sarama, 2004). NCTM (2000) tarafından çocukların şekilleri ayırıp birleştirerek ortaya çıkan sonuçları tahmin etmelerini bir standart olarak belirlenmiştir. Schrier'e (1994) göre imgesel bilgi, düşünme düzeylerinin tamamı ile ilgilidir ve geometrik düşünme becerilerini geliştirir. Clements ve diğerleri (2011) tarafından matematik programı kullanılarak yapılan bir deneysel araştırma sonucunda, çocukların şekilleri oluşturmada büyük gelişim gösterdikleri ve şekilleri zihinsel olarak manipüle ve inşa ettikleri belirlenmiştir. Siew ve diğerleri (2013) tarafından ilkokul 3. sınıf öğrencilerinin geometrik düşünme becerileri gelişiminde van Hiele’nin görsel düzey ve analiz düzeyi üzerine tangramların etkisinin incelendiği araştırma sonucunda, tangramların öğrencilerin geometrik düşünme düzeylerini 
desteklediği bulunmuştur. Araştırmacı bu sebeple, ilkokul matematik programlarında tangramların kullanılmasını önermiştir. Bir şeklin, başka bir şekil ya da birkaç şekille birleştirilmesi çocukların geometri becerilerinin gelişimi açısından önemlidir. 3-7 yaş grubunda toplam 72 çocuğun katıldığ1 ve şekiller ile resimler veya çeşitli tasarımlar oluşturma (deneme-yanılma çalışmalarından şekil özelliklerinin kullanılmasına doğru gidiş), şekilleri birleștirerek yeni şekiller elde etme becerilerinin incelendiği araştırma sonucunda, başlangıçta çocuklar şekilleri oluşturma becerisini gösterememişken ilerleyen aşamalarda şekilleri birleştirme becerisi kazandıkları (başlangıçta deneme yanılma ile) ve daha sonra şekillerden yeni şekil kombinasyonları oluşturarak sentezleme yaptıkları bulunmuştur (Clements vd., 2004). Sarama ve diğerleri (1996) tarafindan yapılan bir başka araştırmada da çocukların yeni bir şekil oluştururken, şekilleri seçip birleştirmede benzer ilerlemeler gösterdikleri görülmüştür. Araştırma sonucunda, başlangıçta çocukların deneme yanılma yöntemini kullandıkları, ardından da bir altıgenin iki yamuktan oluşabileceğini ve yine farklı kombinasyonların olabileceğini fark ettikleri gözlemlenmiştir. Geometrik şekillerin, farklı şekiller kullanılarak oluşturulması ve bir geometrik şekilden farklı şekiller elde edilmesine ilişkin çalışmalar, görsel olarak şekillerin kullanımına ve şekillerin tanımlanmasına etki etmektedir ve geometrik düşünme becerilerinin önemli bir yönünü oluşturmaktadır (Clements vd., 2004).

Çocukların şekli-zemin ilişkisinde yüksek düzeyde başarı gösterdikleri ama yaşla birlikte artış göstermesine rağmen perspektif alma becerilerinin genel olarak düşük düzeyde olduğu tespit edilmiştir. Buradan elde edilen sonuçlar ışında çocukların mekânsal becerilerinin de yaşla birlikte gelişim gösterdiği, ancak perspektif alma becerisinin tüm yaş grupları için düşük düzeyde olduğu ifade edilebilir. Yapılan araştırma sonuçları incelendiğinde çocukların perspektif alma becerilerinin erken dönemde düşük düzeyde olduğu sonucu doğrulanmıştır (Aaten vd.,2011;Rigal, 1996).

Daha önceki sonuçlar ile paralel biçimde çocukların örüntülere verdikleri doğru cevaplar da yaşa göre artış göstermiştir. Elde edilen bu sonuç ilgili alan yazındaki bulgular ile örtüşmektedir. Sarama ve Clements (2004), matematik öğrenimi için temel gereksinimlerin geometri ve örüntü olduğunu belirtmişlerdir. Okul öncesi dönemdeki çocuklar şekilleri ve örüntüleri keşfettikleri, çizimler yaptıkları, geometrik tasarımlar oluşturdukları zaman, gördükleri şekilleri tanımaktan ve isimlendirmekten zevk alırlar (Clements, 1999b). Mozaikler, yap-bozlar, çizimler ve örüntüler gibi etkinlikler, çocukların görsel yapılar oluşturmalarını desteklemektedir. Bunun gibi etkinlikler, şekillerin özellikleri ve şekiller ile ilgili bilgileri de geliştirmektedir (van Hiele, 1999). Ness (2001), araştırmasında 4-5 yaş grubundaki çocukların örüntüleme becerilerinin iyi düzeyde olduğunu tespit etmiştir. Başka bir araştırmada Clements ve diğerleri (2011), deneysel çalışmaları sonucunda uygulanan program ile deney grubundaki çocukların geometri içeriğinde bulunan şekilleri ve 
öğelerini tanıma, şekil kompozisyonu, şeklin bileşimi, geometrik ölçüm, örüntü ve şekilleri karşılaştırma becerilerinde gelişim olduğunu tespit etmişlerdir. Ayrıca Kim ve Sloane (2010), ikinci sınıf öğrencilerinin örüntüleri anlamaları ve örüntülerle ilgili yaşadıkları sorunları belirlemek için yaptıkları araştırma sonucunda, genel olarak ikinci sınıf öğrencilerinin tekrarlayan örüntüleri uzatmada başarılı oldukları görülmüştür. Diğer taraftan, çocukların \% 70 'den fazlasının büyüyen örüntüleri yanlış anladıkları ve bu örüntüler doğru şekilde uzatamadıkları görülmüştür.

Çocukların üç boyutlu cisimleri tanımalarına yönelik beceriler de yaşa göre farklılık göstermiştir. Ayrıca araştırmaya katılan 5 yaş grubundaki çocuklar, küp ve küre cisimlerini isimlendirmekte daha başarılı olmuşlardır. Benzer bir biçimde dikdörtgenler prizması dışında küp ve üçgen prizmaya yönelik üç boyutlu cismin kâğı üzerinde bırakacağı iki boyutlu şeklin tahmininde, çocukların bu becerilerinin yaşa bağlı olarak gelişim gösterdiği görülmüştür.

Şekillerin benzerliği, yapısı, yeri, dönüşümü ve mekânsal akıl yürütme becerisinin gelişimi çocukların mekân becerilerinin yanı sıra matematiğin diğer konularını da anlamalarını kolaylaştırmaktadır. Çocuklar üç boyutlu cisimlerin yüzleri, ayrıtları ve köşeleri arasındaki ilişkileri gördükleri zaman veya örüntüleri tanımlarken mekân içerisinde örüntüler, fonksiyonlar ve hatta cebirin esasları gibi özellikleri fark edebilirler (Copley, 2000). Beşinci ve dokuzuncu sınıf öğrencilerinin, üç boyutlu düşünme yapısının analiz edildiği ve bu düşünme becerisinin mekânsal beceriler ile ilişkisinin araştırıldığı çalışma sonucunda; öğrencilerin mekânsal görselleştirme, mekânsal konumlandırma ve mekânsal ilişkiler gibi faktörlerden oluşan mekânsal becerilerin üç boyutlu geometrik düşünmenin çok güçlü tahmin edici etkeni olarak ortaya çıktığı bulunmuştur (Pittalis ve Christou, 2010). AktaşArnas ve Aslan’a (2010) göre, 1.sınıfa devam eden öğrencilerin üç boyutlu şekilleri tanımada daha başarılı olmalarının sebebi; Türk Ĕ̈itim Sisteminde iki boyutlu şekillerin okul öncesi dönemde, üç boyutlu şekillerin 1. sınıfta öğretilmesi olarak açıklanabilir.

Cinsiyetin çocukların geometri becerilerini etkileyen bir değişken olmadığı belirlenmiştir. Alan yazın incelendiğinde, çocukların şekil seçme becerilerinde (Clements vd., 1999; Kesicioğlu, 2013; Ness, 2001), şekil-mekan-yön kavramlarında (Köse, 2005) ve mekânsal becerilerde (Klein vd., 2010; Ness, 2001; Rosser, Campbell ve Horan, 1986) cinsiyete bağlı farklılık olmadığ1 sonucuna ulaşılan araştırmalar bulunmaktadır. Benzer bulgular, farklı yaş grubundaki öğrencilerin geometrik düşünme düzeylerinin incelendiği araştırmalarda da ortaya çıkmıştır (Halat, 2006; Işıksal ve Aşkar, 2005; Karaman ve Toğrol, 2010). Örneğin Bal (2014), ortaokul öğrencileri ile yaptı̆̆1 bir araştırma sonucunda kız ve erkek öğrencilerin geometrik düşünme puanlarının cinsiyetlerinden etkilenmediği sonucuna ulaşmıştır. 
Yine farklı yaş grubundaki öğrencilerle yapılan araştırma sonuçlarına bakıldığında, erkek öğrencilerin kız öğrencilerden daha başarılı olduğu sonucuna ulaşılmış araştırmalara karşın (Duatepe, 2000; Olkun, Toluk ve Durmuş, 2002), kız öğrencilerin erkek öğrencilerden daha başarılı olduğu sonucuna ulaşılmış araştırma sonuçları da bulunmaktadır (Alex ve Mammen, 2014; Erdoğan, Baloğlu ve Kesici, 2011; Fidan ve Türnüklü, 2010). Araştırmada elde edilen ve cinsiyet değişkeninin, çocukların geometri becerileri üzerinde etkili olmadığı sonucu ile cinsiyete göre farklılık gözlenen araştırma sonuçları birlikte değerlendirildiğinde, okul öncesi dönem ve ilkokulun erken dönemlerinde cinsiyet değişkeninin geometri becerisini etkilemediği; cinsiyete yönelik farklılık gözlenen araştırmalarda ise çocukların ilkokulun ileri sınıflarında ve ortaokul düzeyinde olduğu göze çarpmaktadır. Araştırma sonuçlarının farklılık göstermesinin sebepleri arasında örneklemlerin farklı olması ve ölçme araçlarının farklı olması da sayılabilir.

Sonuç olarak araştırmada çocukların geometri becerilerinin incelenmesi ile teorik olarak tartışma olanağ1 elde edilmiştir. Bu bağlamda araştırma sonuçları incelendiğinde, araştırmaya katılan 5-7 yaş grubu çocukların, şekillerin tipik (prototip) örneklerini ayırt etmede sorun yaşamadıkları; ancak şekillerin oran, döndürme, açıklık, kapalılık gibi özelliklerinden olumsuz etkilendikleri belirlenmiştir. Bu sonuca göre çocukların, şekilleri görünüşlerine göre ayırt etme becerilerinin tipik örnek (prototip) etkisinde olduğu görülmektedir. Bu sonuç van Hiele’nin “Görsel Düzey”inin varllğını desteklemektedir. Araştırmada van Hiele’in teorisine uygun olmayan sonuç, çocukların çoğunluğunun, şekillerin kenar ve köşe özelliklerine yönelik hali hazırda var olan bilgilerinin tespitine yönelik bulgudur. van Hiele’in görsel düzeyde bulunduklarını varsaydığı bu yaş grubundaki çocukların, bir sonraki düzey olan tanımsal düzeye yönelik özellikler sergiledikleri görülmüştür.

Bu bulgular Clements ve diğerlerinin (1999), görsel düzeyden önce tanıma öncesi düzeyin (prerecognitive) var olduğu, van Hiele'nin görsel düzey olarak belirlemiş olduğu düzeyin yeniden bütünleşik (syncretic) düzey şeklinde kavramsallaştırılması gerektiği tezini destekler niteliktedir. Çünkü sözel açıklamaya dayalı bilgilerin ve imgesel bilgilerin sentezlenmesi ve bunların birbirleri ile etkileşim içerinde olduğu ileri sürülmüştür (Aslan, 2004; Aslan ve Aktaş-Arnas, 2007; Clements ve Battista, 1992; Clements vd., 1999; Koleza ve Giannisi, 2013; Siew-Yin, 2003) ve araştırmaya katılan çocuklar hem görsel olarak şekilleri ayırt edebilmiş hem de şekillerin köşe ve kenar özelliklerine yönelik sözel bilgilerini sergilemişlerdir.

İlgili alan yazın incelendiğinde, benzer bulgulara ulaşıldığı görülmektedir. Örneğin Clements ve diğerleri (1999) ve Clements (1999a) yaptıkları araştırmalar sonucunda, şekillerin görünüşlerinin genellikle çocukların kararları üzerinde baskın olduğunu ama çocukların bazen şekillerin 
Özelliklerine yönelik açıklamaları da kullandıklarını (sözel bilgi) belirlemişler ve bu bulguları da bütünleşik (syncretic) düzeyin varlığına yönelik kanıt olarak ileri sürmüşlerdir. Aslan ve Aktaş-Arnas (2007), yaptıkları araştırma sonucunda, araştırmaya katılan 3-6 yaş grubundaki çocukların, doğrudan görsel düzeyden tanımsal düzeye geçemediklerini ve bu iki düzeyin aynı anda var olduğuna yönelik bulgular elde etmişlerdir. Hung ve Fang (2010), yaptıkları çalışmada araştırmaya katılan çocukların bazılarının şekilleri seçerken, şeklin özelliğine yönelik açıklamalar yaptığını tespit etmişlerdir. Bir başka araştırmada da kare ve çember şekilleri için en baskın cevabın, şeklin özelliğine ilişkin cevap olarak kabul edilen kenar sayısı olduğu görülmüştür (Siew-Yin, 2003). Yine başka bir araştırmada Koleza ve Giannisi (2013), okul öncesi dönemde olan çocukların şekilleri seçerken hem görsel hem de şekillerin özelliklerine yönelik kararlar verdiklerini tespit etmişlerdir. Çocuklar tarafından şekillere yönelik özellikler olarak kenar ve köşe sayıları ifade edilmiştir. Araştırma sonucunda, ilişkisel düşünme şeklinin erken yaşta görülmeye başlandığı belirlenmiştir. Ayrıca Turan Topal (2010), 4-6 yaş grubu çocukların bir şeklin, bir şekil grubuna neden üye olduğu ya da olmadığına dair verdikleri yanıtlar sonucunda; yanıtların \% 67'sinin şeklin görünüş özellikleri ile ilgili yanıtlar olduğunu, buna karşın \% 29'unun niteliksel yanıtlar olduğunu saptamıştır. Collins ve Dooley (2013), 4-8 yaş grubundaki çocukların hem görsel hem de özellik temelli cevaplar verdiklerini belirlemişlerdir. Aslan (2004), yaptığı çalışmada 3-6 yaş grubundaki çocukların şekilleri sınıflandırırken, çoğunlukla şekillerin belirsiz özelliklerine odaklandıklarını, şeklin belirli özelliklerini göz ardı ettiklerini belirlemiştir. Bu bulguların yanı sıra araştırmaya katılan çocukların yaşla birlikte, şekillerin belirleyici özelliklerine daha fazla dikkat ettikleri sonucuna ulaşılmıştır. Liu ve diğerlerine (2010) göre, öğrencilerin geometrik kavramları algılamaları görsel ve tanımsal düzeyde gelişim göstermektedir.

Yukarıda yer verilen van Hiele'in geometrik düşünme düzeyleri teorisine yönelik farklı bulguların içeriği, şekillerin görünüşleri ve şekillerin özellikleri boyutundadır. Ama yapılan araştırmada çocukların şekil çizme, şekilleri zihinden döndürme, şekilleri zihinden döndürüp birleştirerek yeni şekli oluşturma, şekilleri birleştirerek ya da bir şekli uygun biçimde ayırarak yeni şekiller oluşturma, örüntüyü devam ettirme, perspektif alma, bloklarla inşa, üç boyutlu cisimleri tanıma ve üç boyutlu cismin bir yüzeyini tahmin etme gibi birçok farklı beceriyi sergiledikleri sonucuna ulaşılmıştır. Tirosh ve diğerleri (2013), yaptıkları araştırmada çocukların farklı etkinliklerde, farklı beceriler gösterdiğini ve geometrik düşünme düzeylerinin birbirinden ayrı olmadığını ileri sürmüşlerdir.

Çocukların sergiledikleri tüm becerilere yönelik bulgular, Clements ve diğerlerinin (1999) ileri sürdüğü syncretic düzeye çok önemli kanıtlar olarak değerlendirilebilir. Ayrıca yapılan bazı araştırmalar sonucunda, birbirlerinden ayrı olarak belirtilen geometrik düşünme düzeylerinin statik 
ve ayrık olmadığını, öğrencilerin farklı sorularda farklı düzey özellikleri sergilediğini, düzeylerin dinamiklik ve süreklilik gösterdiğini ve düzeylerin karakteristik özelliklerinin arttırılmasının gerekliliğinin yanında, öğrencilerin geometrik düşünme düzeylerindeki gelişmenin de farklı oranlarda olduğu sonucuna ulaşılmıştır (Burger ve Shaughnessy, 1986; Clements ve Battista, 1992; Fuys, Geddes ve Tischler, 1988). Tüm bu sonuçlar birlikte değerlendirildiğinde, van Hiele'nin teorisinin yeninde gözden geçirilmeye ihtiyaç duyduğu ve bu konuda derinlemesine araştırmalar yapılması gerektiği düşünülmektedir.

\section{KAYNAKÇA}

Aaten, A. B., van den Heuvel-Panhuizen, M., \& Elia, I. (2011). Kindergartners' perspective taking abilities. Marta Pytlak, Tim Rowland, Ewa Swoboda (Edit.) in Proceedings of the Seventh Congress of the European Society for Research in Mathematics Education, University of Rzeszów, Poland, 1812-1822.

Akbay Şener, P. (2012). Cross-sectional study on grades, geometry achievement and van Hiele geometric thinking levels (Yayımlanmamış Yüksek Lisans Tezi), Boğaziçi Üniversitesi, İstanbul.

Aktaş Arnas, Y. (2002). Okul öncesi dönemi çocuklarda sayı kavramının kazanılması. Çoluk Çocuk Dergisi, 14, 14-17.

Aktaş Arnas, Y., \& Aslan, D. (2010). Children's classification of geometric shapes. Cukurova Üniversitesi Sosyal Bilimler Enstitüsü Dergisi, 19(1), 254-270.

Akuysal Aydoğan, S. ve Şen, S. (2011). 6 Yaş Çocuklarının Sayı Kavramının Gelişiminde Kavram Ĕ̈itim Programının Etkisinin İncelenmesi. Adnan Menderes Üniversitesi Ë̆itim Fakültesi Ë̆itim Bilimleri Dergisi, 2(1), 38-51.

Alex, J. K., \& Mammen, K. J. (2014). Gender differences amongst South African senior secondary school learners' geometric thinking levels. Mediterranean Journal of Social Sciences, 5(20), 19081915.

Alisinanoğlu, F., Kesicioğlu, O. S., \& Mehmet, M. (2013). Evaluation of pre-school children's development of geometric thought in the UK and Turkey. International Journal of Education and Research, 1(10), 1-10.

Altun, M. (1998). Matematik ögrretimi. Bursa: Alfa Yayınları.

Arnas, Y. (2002). Okul öncesi dönemi çocuklarda sayı kavramının kazanılması. Çoluk Çocuk Dergisi, 14-17.

Aslan, D. (2004). Anaokuluna devam eden 3-6 yas grubu çocuklarmm temel geometrik, şekilleri tanmalarmm ve geometrik șekilleri ayurt etmede kullandıklar kriterlerin incelenmesi (Yayımlanmamış Yüksek Lisans Tezi), Çukurova Üniversitesi, Adana. 
Aslan, D., \& Aktaş Arnas, Y. (2007). Okul öncesi eğitim materyallerinde geometrik şekillerin sunuluşuna ilişkin içerik analizi. Cukurova Üniversitesi Sosyal Bilimler Enstitüsü Dergisi, 16(1), 69-80.

Aslan, D., \& Arnas Aktaş, Y. (2007). Three-to six-year-old children's recognition of geometric shapes. International Journal of Early Years Education, 15(1), 83-104.

Aydın, S. (2009). Okul öncesi eğitimcilerinin matematik ögretimiyle ilgili düşünceleri ve uygulamalarmm değerlendirilmesi (Yayımlanmamış Yüksek Lisans Tezi), Karadeniz Teknik Üniversitesi, Trabzon.

Bal, P. A. (2014). Predictor variables for primary school students related to van Hiele geometric thinking. Journal of Theory and Practice in Education, 10(1), 259-278.

Burger, F. W., \& Shaughnessy, J. M. (1986). Characterizing the van Hiele levels of development in geometry. Journal for Research in Mathematics Education, 17(1), 31-48.

Clements, D. H. (1999a). Geometric and spatial thinking in young children. Juanita. V. Copley (Ed.), Mathematics in the Early Years içinde (s. 66-79). Reston, VA: NCTM \& Washington D.C.: NAEYC.

Clements, D. H. (1999b). The geometric world of young children. Scholastic Early Childhood Today, 13(2), 34-43.

Clements, D. H., \& Sarama, J. (2004). Building blocks for early childhood mathematics. Early Childhood Research Quarterly, 19, 181-189.

Clements, D. H., Wilson, D. C., \& Sarama, J. (2004). Young children's composition of geometric figures: A learning trajectory. Mathematical Thinking And Learning, 6(2), 163-184.

Clements, D. H., \& Sarama, J. (2000). The earliest geometry. Teaching Children Mathematics, 7(2), 8286.

Clements, D. H., \& Battista, M. T. (1992). Geometry and spatial reasoning. D. A. Grouws (Ed.), Handbook of Research on Mathematics Teaching and Learning içinde (s. 420-464). New York: Macmillan.

Clements, D. H., Sarama, J., Spitler, M. E., Lange, A. A., \& Wolfe, C. B. (2011). Mathematics learned by young children in an intervention based on learning trajectories: A large-scale cluster randomized trial. Journal for Research in Mathematics Education, 42(2), 127-166.

Clements, D. H., Swaminathan, S., Hannibal, M., \& Sarama, J. (1999). Young children's concepts of shape. Journal for Research in Mathematics Education, 30(2), 192-212.

Cohen, L., Manion, L., \& Morrison, K. (2005). Research Methods in Education (5th edition). New York: Routledge Falmer.

Collins, E., \& Dooley, T. (2013). Junior primary pupils' understanding of 2D shapes. Proceedings Fifth Conference on Research in Mathematics Education MEI 5, 5th and 6th September 2013 St. Patrick's College, Drumcondra, Dublin 9. Editors: Thérèse Dooley, Siún NicMhuirí, Maurice OReilly \& Ronan Ward, p.101-112. 
Copley, J. V. (2000). The young child and mathematics. Washington, DC: National Association for The Education of Young Children.

Crowley, M. L. (1987). The van Hiele model of the development of geometric thought. Mary Montgomery Lindquist (Ed.), Learning and Teaching Geometry içinde K-12, (s. 1-16) RESTON, VA.: National Council af Teachers af Mathematics.

Çalıkoğlu Bali, G., \& Boz, M. (2004). Çocuklarda geometrik algılama. OMEP 2003 Dünya Konsey Toplant1s1 ve Konferans1, Bildiriler Kitab1 2, 393-410.

Çelebi Akkaya, S. (2006). van Hiele düzeylerine göre hažrlanan etkinliklerin ilköğretim 6. sinf öğrencilerinin tutumuna ve başarısına etkisi (Yayımlanmamış Yüksek Lisans Tezi), Abant İzzet Baysal Üniversitesi, Bolu.

Dere, H. (2000). Okul öncesi eğitim kurumlarna devam eden altı yaş çocuklarna baæ̌ matematik kavramlarm kaz̧andırmada yapılandırılmıs ve geleneksel yöntemlerin karşılaştınlması (Yayımlanmamış Yüksek Lisans Tezi). Gazi Üniversitesi, Ankara.

Develi, M. H., \& Orbay, K. (2003). İlköğretimde niçin ve nasıl bir geometri öğretimi. Milli Ĕğtim Dergisi, 157, 115-122.

Duatepe, A. (2000). An investigation on the relationship between van Hiele geometric level of thinking and demographic variables for preservice elementary school teachers (Yayımlanmamış Yüksek Lisans Tezi), Orta Doğu Teknik Üniversitesi, Ankara.

Erbay, F. (2009). Anasimfina devam eden altı yas çocuklarna verilen yaratıcı drama eğitiminin çocuklarm işitsel mubakeme ve işlem becerilerine etkisinin incelenmesi (Yayımlanmamış Doktora Tezi), Selçuk Üniversitesi, Konya.

Erdoğan, A., Baloğlu, M., \& Kesici, Ş. (2011). Gender differences in geometry and mathematics achievement and self-efficacy beliefs in geometry. Eurasian Journal of Educational Research, 43, 91-106.

Erdoğan, T., Akkaya, R., \& Akkaya Çelebi, S. (2009). The effect of the van Hiele model based instruction on the creative thinking levels of 6th grade primary school students. Educational Sciences: Theory \& Practice, 9(1), 181-194.

Ergün, S. (2003). Okul öncesi eğitim alan ve almayan ilköğretim birinci sinf ögrencilerinin matematik yetenek ve başarlarmmn karşılaştırmalı olarak incelenmesi (Yayımlanmamış Yüksek Lisans Tezi), Marmara Üniversitesi, İstanbul.

Fidan, Y., \& Türnüklü, E. (2010). İlköğretim 5. sınıf öğrencilerinin geometrik düşünme düzeylerinin bazı değişkenler açısından incelenmesi. Pamukkale Üniversitesi Eğitim Fakültesi Dergisi, 27, 185-197.

Fisher, K. R., Hirsh-Pasek, K., Newcombe, N., \& Golinkoff, R. M. (2013). Taking shape: Supporting preschoolers' acquisition of geometric knowledge through guided play. Child development, 84(6), 1872-1878. 
Fuys, D., Geddes, D., Lovett, C. J., \& Tischler, R. (1988). The van Hiele model of thinking in geometry among adolescents [monograph number 3]. Journal for Research in Mathematics Education. Reston, VA: NCTM.

Greenstein, S. (2011). The development of young children's qualitative geometric reasoning. Paper presented at the Research Presession of the Annual Meeting of the National Council of Teachers of Mathematics Indianapolis, April 11 - 13, s.2-19.

Hacısalihoğlu, H. H., Mirasyedioğlu, Ş., \& Akpınar, A. (2003). Matematik öğretimi: ilköğretim 1-5. Ankara: Asil Yayın Dağıtım.

Halat, E. (2006). Sex-related differences in the acquisition of the van Hiele levels and motivation in learning geometry. Asia Pacific Education Review, 7(2), 173-183.

Hannibal, M. A. (1999). Young children's developing understanding of geometric shapes. Teaching Children Mathematics, 5(6), 353-357.

Hannibal, M. A. Z., \& Clements, D. H. 2000. Young children's understanding of basic geometric shapes, Arlington, VA: National Science Foundation. grant no. ESI-8954644

Hoffer, A. (1981). Geometry is more than proof. Mathematics Teacher, 74(1), 11-18.

Hung, W. T., \& Fang, C. H. (2010). Exploring geometric cognition of young children. http://ir.meiho.edu.tw/bitstream/987654321/1147/1/\%E9\%A6\%AC $\% \mathrm{E} 4 \% \mathrm{BE} \% 86 \%$ $\mathrm{E} 8 \% \mathrm{~A} 5 \% \mathrm{BF} \% \mathrm{E} 4 \% \mathrm{BA} \% 9 \mathrm{E} \% \mathrm{E} 7 \% \mathrm{~A} 0 \% 94 \% \mathrm{E} 8 \% \mathrm{~A} 8 \% 8 \mathrm{E} \% \mathrm{E} 6 \% 9 \mathrm{C} \% 83 \_\mathrm{Exploring}+\mathrm{Ge}$ ometric+Cognition+of+Young+Children_.pdf

Isiksal, M., \& Askar, P. (2005). The effect of spreadsheet and dynamic geometry software on the achievement and self-efficacy of 7th-grade students. Educational Research, 47(3), 333-350.

İrkörücü, S. (2006). Okul öncesi eğitim kurumuna devam eden altı yaşındaki çocuklara uygulanan ev odakeh matematiksel destek programmin çocuklarn matematiksel kavram edinimine etkisinin incelenmesi (Yayımlanmamış Yüksek Lisans Tezi), Gazi Üniversitesi, Ankara.

Karaman, T., , \& Toğrol, A. Y. (2010). Relationship between gender, spatial visualization, spatial orientation, flexibility of closure abilities and performance related to plane geometry subject among sixth grade students. Bogazici University Journal education, 26(1), 1-25.

Karasar, N. (2013). Bilimsel araștırma yöntemleri. (25. Basım). Ankara: Nobel Yayıncılık.

Kaur, J. (2012). Children's understanding of the geometrical concepts: Implications for teaching geometry. Proceedings of NIME National Conference on Mathematics Education, January 20-22, Mumbai, India.

Kesicioğlu, O. S. (2011). Doğrudan ögretim yöntemiyle hą̧rlanan eğitim programınn ve bu yönteme göre bažrlanan bilgisayar destekli eğitim programmm okul öncesi çocuklarmm geometrik, şekil kavramlarm ögrenmelerine etkisinin incelenmesi (Yayımlanmamış Doktora Tezi), Gazi Üniversitesi, Ankara.

Kesicioğlu, O. S. (2013). The effect of gender and computer use variables on recognation of geometrical shapes in preschool children. International Journal on New Trends in Education and Their Implications, 4(3), 48-56. 
Kesicioğlu, O. S., Alisinanoğlu, F., \& Tuncer, A. T. (2011). The analysis of kindergarteners` recognition degrees of geometric shapes. Elementary Education Online, 10(3), 1093-1111.

Kılıç, Ç., Köse, N. Y., Tanışlı, D., \& Özdaş, A. (2007). Determining the fifth grade students' van Hiele geometric thinking levels in tessellation. Elementary Education Online, 6(1), 11-23.

Kurlar, B. (2006). Okulöncesi eğitim kurumuna devam eden altı yas çocuklarna bąı matematiksel kavramlar kazandirmada yapılandirlmıs yöntem ile geleneksel yöntemin etkinliğinin karşlaștırlmalı olarak incelenmesi (Yayımlanmamış Yüksek Lisans Tezi), Selçuk Üniversitesi, Konya.

Kim, S. H., \& Sloane, F. (2010). Second Grade Children's Understandings And Difficulties With Patterns. (Eds: Brosnan, P., Erchick, D. B., ve Flevares, L.) Proceedings of the 32nd annual meeting of the North American Chapter of the International Group for the Psychology of Mathematics Education. Columbus, $\mathrm{OH}$ : The Ohio State University.

Koleza, E., \& Giannisi, P. (2013). Kindergarten children's reasoning about basic geometric shapes. Editors Behiye Ubuz, Çiğdem Haser, Maria Alessandra Mariotti Proceedings of the Eight Congress of the European Society for Research in Mathematics Education 6-10 February 2013 Antalya - Turkey, 21182127.ttp://cerme8.metu.edu.tr/wgpapers/WG13/WG13_Koleza.pdf

Köse, A. (2005). Anasinfina devam eden 6 yas grubu çocuklarn şekil-mekan-yön kavramlarn eğitimlerinde mürik etkinliklerinin etkisinin incelenmesi (Yayımlanmamıs Yüksek Lisans Tezi), Gazi Üniversitesi, Ankara.

Liu, Y., Zhang, P., Brosnan, P., \& Erchick, D. (2010). Examining the geometry content of state standardized exams using the van Hiele model. Brosnan, P., Erchick, D. B., \& Flevares, L. (Eds.). (2010). Proceedings of the 32nd annual meeting of the North American Chapter of the International Group for the Psychology of Mathematics Education. Columbus, $\mathrm{OH}$ : The Ohio State University, VI, 616-624.

National Council of Teachers of Mathematics (NCTM, 2000). Principles and standards for school mathematics. Vol. 1. Reston, VA.

Ness, D. (2001). The Development of Spatial Thinking, Emergent Geometric Concepts and Architectural Principles in The Everday Context. The Graduate School of Arts and Sciences, Columbia University. UMI Number: 9998197

Olkun, S., \& Toluk-Uçar, Z. (2007). İlkögrretimde etkinlik temelli matematik ögretimi. Ankara: Maya Akademi.

Olkun, S., Toluk, Z., \& Durmuş, S. (2002). Matematik ve sınıf öğretmenliği birinci sınıf öğrencilerinin geometrik düşünme düzeyleri. 5. Ulusal Fen Bilimleri ve Matematik Eğitimi Kongresi Bildiriler, 2, 1064-107.

Ölekli, N. (2009). 5-6 yaş çocuklarnda matematiksel şekil algısı ve sayı kavrammm gelişiminde drama yönteminin etkisi (Yayımlanamış Yüksek Lisans Tezi), Selçuk Üniversitesi, Konya.

Ömercikoğlu, H. (2006). 4-7 yaş arası çocuklarm sayı kavramlarmm Piaget'nin birebir eşleme deneyleri ile incelenmesi (Yayımlanmamış Yüksek Lisans Tezi), Marmara Üniversitesi, İstanbul. 
Önkol, L. F. (2012). Erken Sayı Testi'nin uyarlanması ve Erken Sayı Gelisim Programi'nın altı yaş çocuklarn sayn gelisimlerine etkisinin incelenmesi (Yayımlanmamıs Doktora Tezi), Marmara Üniversitesi, İstanbul.

Özerem, A. (2012). Misconceptions in geometry and suggested solutions for seventh grade students. International Journal of New Trends in Arts, Sportser Science Education, 1(4), 23-35.

Pesen, C. (2003). Matematik ögretimi. Ankara: Nobel Yayınları.

Pittalis, M., \& Christou, C. (2010). Types of reasoning in 3D geometry thinking and their relation with spatial ability. Educational Studies in Mathematics, 75(2), 191-212.

Polat Unutkan, Ö. (2007). Okul öncesi dönem çocuklarının matematik becerileri açısından ilköğretime hazır bulunuşluğunun incelenmesi. Hacettepe Üniversitesi Eğitim Fakültesi Dergisi, 32, 243-254.

Poyraz, H., \& Turhan, G. (2006). Anasınıfına devam eden alt sosyo-ekonomik düzeydeki çocuklara uygulanan matematiksel kavramları destekleyici eğitim programının cümle ve sayı olgunluk puanlarına olan etkisinin incelenmesi. Gaẓi Üniversitesi Mesleki Eğitim Fakültesi Dergisi, 1(1), 147-161.

Rigal, R. (1996). Right-left orientation, mental rotation, and perspective-taking: When can children imagine what people see from their own viewpoint? Perceptual and Motor Skills, 83(3), 831842.

Rønning, F. (2004). Language and concept development in geometry. In Proceedings of the 28th Conference of the International (Vol. 4, pp. 137-144). http://emis.ams.org/proceedings/PME28/RR/RR125_Ronning.pdf

Rosser, R. A., Campbell, K. P., \& Horan, P. F. (1986). The differential salience of spatial information features in the geometric reproductions of young children. The Journal of Genetic Psychology, 147(4), 447-455.

Sancak, Ö. (2003). Okulöncesi eğitim kurumlarna devam eden 6 yas çocuklarna sayn ve şekil kavramlarmm kazandirlmasinda bilgisayar destekli eğitim ile geleneksel eğitim yöntemlerinin karşılasstrrlması (Yayımlanmamış Yüksek Lisans Tezi), Gazi Üniversitesi, Ankara.

Sarama, J., \& Clements, D. H. (2003). Building blocks of early childhood mathematics. Teaching Children Mathematics, 9, 480-484.

Sarama, J., Clements, D. H., \& Vukelic, E. B. (1996). The role of a computer manipulative in fostering specific psychological/mathematical processes. In E. Jakubowski, D. Watkins, \& H. Biske (Ed.), Proceedings of the Eighteenth Annual Meeting of the North America Chapter of the International Group for the Psychology of Mathematics Education (pp. 567-572). Columbus, OH: ERIC Clearinghouse for Science, Mathematics, and Environmental Education

Sarıtaş, R. (2010). Milli Eğitim Bakanlŭğ okul öncesi eğitim programuna uyarlanmıs GEMS (Great Explorations in Math and Science) fen ve matematik programmm anaokuluna devam eden alt yas grubu cocuklarn kavram edinimleri ve okula haz̨r bulunusluk düzeyleri üzerindeki etkisinin incelenmesi (Yayımlanmamıs Yüksek Lisans Tezi), Gazi Üniversitesi, Ankara.

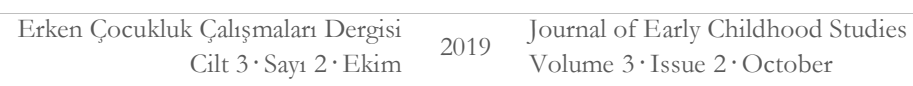


Schrier, D. M. (1994). The development of young children's geometry thinking in a mediated kindergarten classroom environment (ProQuest Dissertations and Theses), State University of New York, Buffalo.

Sezer, T. (2008). Okul öncesi eğitim alan beş yaş grubu çocuklara sayı ve işlem kavramlarm kazandırmada drama yönteminin etkisinin incelenmesi (Yayımlanmamıș Yüksek Lisans Tezi), Abant İzzet Baysal Üniversitesi, Bolu.

Sezer, T., \& Güven, Y. (2016). Erken Geometri Beceri Testinin Geliştirilmesi. Atatürk Üniversitesi Kažm Karabekir Eğitim Fakültesi Dergisi, 33, 1-22.

Sezer, T., \& Güler-Öztürk, D. S. (2011). The effects of drama in helping five-year-old children acquire the concepts of number and operation. Educational Research, 2(6), 1210-1218.

Sezer, T., Güral, M., Güven, G., \& Efe-Azkeskin, K. (2013). Investigation of number and operations skills of children attending preschool education. Journal of Educational and Instructional Studies in the World, 3(1), 15-21.

Siew, N. M., Chong, C. L., \& Abdullah, M. R. (2013). Facilitating students'geometric thinking through van Hiele's phase-based learning using tangram. Journal of Social Sciences, 9(3), 101 111.

Siew-Yin, H. (2003). Young children's concept of shape: van Hiele visualization level of geometric thinking. The Mathematics Educator, 7(2),71-85.

Szinger, I. S. (2008). The evolvement of geometrical concepts in lower primary mathematics (Parallel and Perpendicular). Annales Mathematicae et Informaticae, 35, 173-188.

Taşkın, N. (2012). Coklu ögrenme ortammmn okul öncesi ögrencilerinin sayı kavramı gelişimine etkisi (Yayımlanmamış Yüksek Lisans Tezi), Karadeniz Teknik Üniversitesi, Trabzon.

Terzi, M. (2010). van Hiele geometrike düsünme düzeylerine göre tasarlanan öğretim durumlarmm ögrencilerin geometrik bașar ve geometrik düsünme becerilerine etkisi (Yayımlanmamış Doktora Tezi), Gazi Üniversitesi, Ankara.

Thirumurthy, V. (2003). Children's cognition of geometry and spatial reasoning: A cultural process. (ProQuest Dissertations and Theses), State University of New York, Department of Learning and Instruction. UMI Number: 3102411.

Tirosh, D., Tsamir, P., Levenson, E., Tabach, M., \& Barkai, R. (2013). Two children, three tasks, one set of figures: Highlighting different elements of children's geometric knowledge. Behiye Ubuz, Çiğdem Haser, Maria Alessandra Mariotti (Editors) Proceedings of the Eight Congress of the European Society for Research in Mathematics Education 6-10 February 2013 Antalya - Turkey, 2228-2237.

Tsamir, P. Tirosh, D., \& Levenson, E. (2008). Intuitive nonexamples: The case of triangles. Educational Studies in Mathematics, 69(2), 81-95.

Turan Topal, Y. (2010). Okul öncesi çağındaki çocuklar ögretilen geometri kavramlarm nasıl algzlarlar? (Yayımlanmamış Yüksek Lisans Tezi), Gazi Üniversitesi, Ankara. 
Turhan, G. (2004). Anasmefina devam eden alt sosyo-ekonomik düreydeki çocuklara uygulanan Matematiksel Kavramlarn Destekleyici Eğitim Programinm cümle ve sayn olgunluğuna etkisinin incelenmesi (Yayımlanmamış Yüksek Lisans Tezi), Gazi Üniversitesi, Ankara.

Ubuz, B. (1999). 10. ve 11. sınıf öğrencilerinin temel geometri konularındaki hataları ve kavram yan1lg1ları. Hacettepe Üniversitesi Eğitim Fakültesi Dergisi, 16-17, 95-104.

Usiskin, Z. P. (1982). van Hiele Levels and Achievement in Secondary School Geometry. (Final Report of the Cognitive Development and Achievement in Secondary School Geometry Project). Chicago, IL: University of Chicago, Department of Education. (ERIC No. ED 220 288).

van Hiele, P. M. (1986). Structure and insight: A theory of mathematics education. Orlando, FL: Academic Press.

Van Hiele, P. M. (1999). Developing geometric thinking through activities that begin with play. Teaching Children Mathematics, 5(6), 310-316.

Vighi, P. (2003). The triangle as a mathematical object. European Research in Mathematics Education III Congress Proceedings. Bellaria, Italy, 28 February - 3 March 2003, 1-10. http://www.mathematik.unidortmund.de/ erme/CERME3/Groups/TG7/TG7_Vighi _cerme3.pdf

Yalım, N. (2009). 5-6 yaş çocuklarnda matematiksel şekil algısı ve sayı kavrammm gelişiminde drama yönteminin etkisi (Yayımlanmamış Yüksek Lisans Tezi), Selçuk Üniversitesi, Konya.

Yilmaz, E. (2006). Okul öncesi eğitim kurumlarna devam eden 6 yas çocuklarmm sayı ve işlem kavramlarm kaz̧anmalarnda müzikli oyun etkinliklerinin kullanılmasımn etkisi (Yayımlanmamış Yüksek Lisans Tezi), Çukurova Üniversitesi, Adana.

Y1lmaz, S. (2011). 7. sinnf ögrencilerinin 'doğrular ve açlar' konusundaki hata ve kavram yanılgularmmn van Hiele geometri anlama düzeyleri açısından analiæi (Yayımlanmamış Yüksek Lisans Tezi), Kastamonu Üniversitesi, Kastamonu.

Yılmaz, S., Turgut, M., \& Kabakçı, D. A. (2008). Ortaöğretim öğrencilerinin geometrik düşünme düzeylerinin incelenmesi: Erdek ve Buca örneği. Bilim, Eğitim ve Düsünce Dergisi, 8(1).

Yiğit, T. (2008). Okulöncesi eğitim kurumlarnda Montessori ve geleneksel ögrretim yöntemleri alan çocuklarm sayı kavramm kaz̧anma davranışlarmm karşılaștırlması (Yayımlanmamış Yüksek lisans Tezi), Selçuk Üniversitesi, Konya. 